\title{
Flowering and Growth of Phalaenopsis Orchids following Growth Retardant Applications
}

\author{
Yin-Tung Wang ${ }^{1}$ \\ Department of Horticultural Sciences, Texas A\&M University Agricultural \\ Research and Extension Center, 2415 East Highway 83, Weslaco, TX 78596 \\ Tsung-Yao $\mathbf{H s u}^{2}$ \\ Orchid Propagation Center, Taiwan Sugar Corporation, 148, Wulin Tsun, \\ Houpi Hsiang, Tainan, Taiwan, R.O.C.
}

Additional index words. plant growth regulator, moth orchid

\begin{abstract}
Bare-root, mature, hybrid Phalaenopsis seedlings were dipped in one of three growth retardant solutions for 5 seconds or sprayed with a growth retardant 4 weeks following planting during inflorescence elongation. Dipping the entire plant in daminozide $\left(2500,5000\right.$, or $7500 \mathrm{mg}^{\circ}$ liter $\left.^{-1}\right)$ before planting delayed flowering by 5-13 days, whereas foliar applications had no effect. Paclobutrazol (50, 100, 200, or $\left.400 \mathrm{mg}^{-l_{i t e r}}{ }^{-1}\right)$ or uniconazole $\left(25,50,100\right.$, or $\left.200 \mathrm{mg} \cdot l i t e r^{-1}\right)$ dips did not affect the bloom date but effectively restricted inflorescence growth below the first flower (stalk). Increasing concentrations produced progressively less growth. Foliarly applied retardant treatments were less effective than dipping. Flower size, flower count, and stalk thickness were unaffected by treatments. Dipping in high concentrations of paclobutrazol (200 or $\left.400 \mathrm{mg} \cdot \mathrm{liter}^{-1}\right)$ or uniconazole (100 or $\left.200 \mathrm{mg}^{-} \mathrm{liter}^{-1}\right)$ caused plants to produce small, thick leaves. During the second bloom season, inflorescence emergence and bloom date were progressively delayed by increasing concentrations of paclobutrazol and uniconazole. Neither retardant affected flower count or size. Foliarly applied daminozide increased stalk length. In another experiment, foliar paclobutrazol treatment restricted stalk growth more effectively when sprayed before inflorescence emergence. Its effect progressively decreased when treatment was delayed. Paclobutrazol concentrations from 125 to $500 \mathrm{mg} \cdot l i t e r^{-1}$ were equally effective in limiting stalk elongation when applied to the foliage. Chemical names used: butanedioic acid mono (2,2-dimethylhydrazide) (daminozide); (E)-1- ( $p$-chlorophenyl)-4,4dimethyl-2-(1,2,4-triazol-1-yl)-1-penten-3-ol(uniconazole); (2RS, $3 R S)$-1-(4-chlorophenyl)4,4-dimethyl-2-(1 H-1,2,4-triazol-1-yl) pentan-3-ol (paclobutrazol).
\end{abstract}

The demand for Phalaenopsis (moth orchid) as a potted flowering plant has increased rapidly in recent years (Thomas, 1992; Vasquez and Frier, 1991). In addition to domestic propagation, >250,000 plants were imported to the United States in 1992. This orchid has a relatively low light requirement (Poole and Seeley, 1977; Taiwan Sugar Corp., 1989) and a bloom period often surpassing 2-3 months. Phalaenopsis is easier to grow than many other orchids (Gordon, 1990; McDowell, 1992; Wang, 1992).

One goal of current breeding research is to introduce more compact selections of moth orchids for the commercial trade. Although dwarf cultivars with small flowers are avail-

\footnotetext{
Received for publication 21 June 1993, Accepted for publication 5 Nov. 1993. Some plants used in this study were donated by Taiwan Sugar, Taipei, Taiwan, R.O.C. Uniconazole was donated by Valent U.S.A., Walnut Creek, Calif. The cost of publishing this paper was defrayed in part by the payment of page charges. Under postal regulations, this paper therefore must be hereby marked advertisement solely to indicate this fact,

Associate Professor of Floriculture, 'Chief Propagator.
}

able (Gavin and Griesbach, 1991; Griesbach, 1985), most Phalaenopsis cultivars with large flowers have long inflorescences, which results in high shipping costs for the taller boxes that must be used. An assessment of commercially available growth retardants for controlling inflorescence length would be helpful. Because Phalaenopsis is a perennial and often reblooms for the consumer, the long-term effect of growth retardants on future growth and flowering must be evaluated. Therefore, our experiments were conducted to determine the immediate and long-term impact of three growth retardants on Phalaenopsis flowering and growth. The effect of paclobutrazol, applied at various stages of inflorescence development, on flowering also was evaluated.

\section{Materials and Methods}

Effect of various growth retardants. Bareroot, mature seedlings of a white-flowered Phalaenopsis hybrid [P. amabilis (L.) Blume $\times P$. Mount Kaala 'Elegance') with five to seven leaves spreading 30-35 cm were imported from Taiwan (Taiwan Sugar Corp., Taipei) by airfreight. Plants were in transit for 9 days and remained turgid with no visible inflorescences on arrival (13 Oct. 1991). Eleven groups of eight plants were immersed for $5 \mathrm{sec}$ in an aqueous solution of daminozide at 2500, 5000 , or $7500 \mathrm{mg} \cdot$ liter $^{-1}$ (B-Nine SP; Uniroyal Chemical, Middlebury, Conn.); paclobutrazol at 50, 100, 200, or $400 \mathrm{mg} \cdot$ liter $^{-1}$ (Bonzi, Sandoz, Chicago); or uniconazole at 25, 50, 100, or $200 \mathrm{mg} \cdot$ liter $^{-1}$ (Sumagic; Valent U.S.A., Walnut Creek, Calif.) immediately following arrival. We dipped control plants in water. Then all plants were planted.

The medium consisted of equal volumes perlite (No. 3; Grace-Sierra, Fogelsville, Pa.) horticultural-grade charcoal, and Metro Mix 250 (Grace-Sierra, Milpitas, Calif.) amended with $250 \mathrm{~g}$ Micromax $/ \mathrm{m}^{3}$ (Grace-Sierra, Milpitas). Among the charcoal particles, 35\% were $>8 \mathrm{~mm} ; 21 \%$ were $8-6.3 \mathrm{~mm} ; 32 \%$ were $6.3-4 \mathrm{~mm}$; and $14 \%$ were $<4 \mathrm{~mm}$.

A total of 48 additional plants were potted, and after 4 weeks when flower spikes had started to elongate, plants were given a foliar spray of water, daminozide (2500 or 5000 $\mathrm{mg} \cdot$ liter $\left.^{-1}\right)$, paclobutrazol (250 or $\left.500 \mathrm{mg} \cdot \mathrm{liter}^{-1}\right)$, or uniconazole (100 or $\left.200 \mathrm{mg} \cdot \mathrm{liter}^{-1}\right)$. All solutions contained $0.05 \%$ Tween 20 (FisherBiotech, Fair Lawn, N.J.). The spray solution was used at an average rate of $12 \mathrm{ml} /$ plant. The medium surface was not covered during spraying to simulate a commercial practice. The air was $27 \mathrm{C}$ at the time of treatment. Single-plant experimental units were replicated eight times. Treatments were arranged in a randomized complete-block design. We conducted regression analyses within each application method, using the concentration of each retardant as the independent variable.

Plants were placed on a greenhouse bench and received a maximum photosynthetic photon flux from 460 (Oct. 199 1) to 270 (Jan. 1992) $\mu \mathrm{mol} \cdot \mathrm{m}^{-2} \cdot \mathrm{s}^{-1}$ at noon. All pots were irrigated by hand with water containing $0.5 \mathrm{~g}$ $20 \mathrm{~N}-8.6 \mathrm{P}-16.6 \mathrm{~K}$ water-soluble fertilizer (Grace-Sierra) per liter.

We started to collect data when the fifth flower opened; our data included first flower width, number of flowers on the main inflorescence, total inflorescence length, and date that the first flower became fully open. We also recorded inflorescence length between the base and first flower (stalk), its diameter at the middle of the fourth internode, and internode length between the first and second flowers.

To determine retardant effects on long-term plant performance, plants were watered, fertilized, and maintained on the same bench. The average greenhouse air was 22.7 (day)/16.5C (night) in Jan. 1992 and 32.9 (day)/25.7C (night) in July 1992.

We started examining the plants daily on 1 Aug. 1992, recording date of inflorescence emergence from a leaf base and data similar to those collected during the previous season. Length and width of the uppermost fully matured leaf were determined. The experiment ended in Apr. 1993.

Effects of paclobutrazol at various stages. Phalaenopsis (Snow Swallow $\times$ Hisa Nasu) plants with 30- to 35-cm leaf span, propagated by tissue culture, were grown in $470 \mathrm{~cm}^{3} \mathrm{New}$ 
Zealand sphagnum moss in soft, clear-plastic, $600-\mathrm{cm}^{3}$ pots $(10.5 \mathrm{~cm}$ in diameter). Plants received 0.4 g.liter ${ }^{-1}$ of a $10 \mathrm{~N}-12.9 \mathrm{P}-16.6 \mathrm{~K}$ water-soluble fertilizer (Grace-Sierra, Milpitas) at each irrigation. Because inflorescence emergence was uniform, plants were selected and sprayed with paclobutrazol on three dates. On 5 Nov. 1992, a total of 20 plants without visible flower bud (pre-emergence) were selected. Half received a foliar application of paclobutrazol, and the other half were controls. An additional two groups of 10 plants, with flower buds just breaking the leaf base (bud stage) or flower buds $1 \mathrm{~cm}$ long, also were treated with paclobutrazol. On 18 Nov., 10 plants with 2.5 -cm-long inflorescences and another 10 plants with 5-cm-long inflorescences were selected and treated. Two groups of 10 plants 7.5- or 10-cm-long inflorescences were selected and treated on 25 Nov. The treatment solution contained $250 \mathrm{mg}$ paclobutrazol/liter and $0.05 \%$ Tween 20 . The medium surface was not covered during treatment to simulate commercial conditions. Each plant received an average of $10 \mathrm{ml}$ of paclobutrazol solution.

To determine the effects of various concentrations of paclobutrazol on flowering, additional plants with 0.5 - to 1.5 -cm-long inflorescences were selected on 18 Nov. Groups of 10 plants each received paclobutrazol $\left(\mathrm{mg} \cdot\right.$ liter $\left.^{-1}\right)$ at 125, 125 twice, 250 twice, or 500 once. We applied the second retardant 1 week after the first. Nontreated control plants and plants receiving $250 \mathrm{mg} \cdot$ liter $^{-1}$ once in the previous experiment were included for comparisons. All plants were arranged in a randomized complete-block design replicated 10 times.

Recollected the following data in mid-Mar. 1993: width of the first flower, number of flowers, length of the stalk, internode length between the first two flowers, and diameter of flower stalk measured at the middle of the fourth internode. Duncan's multiple range test was used for comparing treatment effects.

\section{Results and Discussion}

First season. Dipping the entire plant in daminozide before planting delayed flowering by $5-13$ days ( 2500 and $7500 \mathrm{mg} \cdot$ liter $^{-1}$, respectively); foliar application had no effect (Table 1). Paclobutrazol or uniconazole dips did not affect the bloom date, but effectively restricted stalk elongation. Foliar applications of the two retardants produced limited, but statistically significant, effects. The paclobutrazol dip increased and the uniconazole spray slightly decreased the floral internode length (Table 1). Flower quality (e.g., flower size and number and stalk diameter) were unaffected (data not presented). Similarly, uniconazole and paclobutrazol had no effect on hibiscus Hibiscus rosa-sinensis L. flower size (Wang and Gregg, 1991). Following paclobutrazol or uniconazole treatments, roots were thicker (observation only). There was no statistical difference in the number of lateral inflorescences between treatment and control plants (Table 1).
By Aug. 1992, all plants treated with uniconazole or paclobutrazol dip at 200 or $400 \mathrm{mg} \cdot$ liter $^{-1}$ produced small, thick leaves. All treatments, with the exception of daminozide dips, increased leaf count (Table 1). On plants treated with daminozide and low rates of paclobutrazol, new leaves had round tips.

Second season. Inflorescence emergence during the second blooming season was not affected by daminozide, but it was progressively delayed by increasing concentrations of paclobutrazol and uniconazole (Table 2). Although not compared statistically, dipping plants in uniconazole solution caused a substantial delay in inflorescence emergence compared to a foliar spray of equal concentration, possibly due to increased retardant uptake.

Regression and contrast analyses showed that retardant affected neither flower size (data not shown) nor main inflorescence flower count (Table 2). All plants previously treated with retardants, except daminozide, had shorter stalks than controls. Plants sprayed with daminozide had longer stalks than nontreated

plants. Dipping in uniconazole resulted in thinner stalks.

Daminozide had no effect on leaf size or count, but leaf count was increased by dipping plants in paclobutrazol or spraying with paclobutrazol or uniconazole (Table 2). Uniconazole dip accelerated leaf production at all concentrations except at $200 \mathrm{mg} \cdot \mathrm{liter}^{-1}$. Regardless of application method, plants treated with paclobutrazol or uniconazole had progressively smaller leaves as concentration increased. The effect of uniconazole on restricting leaf size was particularly prominent.

Stage effects. When paclobutrazol was applied before the inflorescences were visible, the stalk length was $45 \%$ that of the control, whereas stalks were only $17 \%$ shorter when treated at the $10-\mathrm{cm}$ stage (Table 3 ). Therefore, as treatment was delayed from preemergence of the inflorescences until the 10$\mathrm{cm}$ stage, paclobutrazol progressively restricted stalk elongation less. Delaying treatment until inflorescences were $\geq 5 \mathrm{~cm}$ increased flower size slightly (Table 3). Paclobutrazol treatments did not affect the average number of flowers.

Table 1. The effect of three growth retardants and their method of application on Phalaenopsis orchid flowering.

\begin{tabular}{|c|c|c|c|c|c|c|}
\hline \multirow[b]{2}{*}{$\begin{array}{l}\text { Retadant } \\
\text { rate } \\
\text { (mg.liter } \\
\text { (m) }\end{array}$} & \multirow[b]{2}{*}{$\begin{array}{l}\text { Days to } \\
\text { first flower } \\
\text { opening }\end{array}$} & \multicolumn{2}{|c|}{ Inflorescence length } & \multirow{2}{*}{$\begin{array}{l}\text { Flower } \\
\text { internode } \\
\text { length }^{2} \\
(\mathrm{~cm})\end{array}$} & \multirow[b]{2}{*}{$\begin{array}{c}\text { No. } \\
\text { laterals }\end{array}$} & \multirow[b]{2}{*}{$\begin{array}{c}\text { No. new } \\
\text { leaves }\end{array}$} \\
\hline & & $\begin{array}{l}\text { Base to } \\
\text { first flower } \\
\text { (cm) }\end{array}$ & $\begin{array}{l}\text { Total } \\
(\mathrm{cm})\end{array}$ & & & \\
\hline \multicolumn{7}{|l|}{ Control } \\
\hline 0 & 117 & 44.7 & 65.7 & 3.8 & 0.0 & 2.1 \\
\hline \multicolumn{7}{|c|}{ Preplant dip } \\
\hline \multicolumn{7}{|l|}{ Daminozide } \\
\hline 2500 & 122 & 48.2 & 72.5 & 4.6 & 0.8 & 2.3 \\
\hline 5000 & 126 & 44.1 & 66.2 & 3.8 & 0.5 & 2.4 \\
\hline 7500 & 130 & 46.3 & 71.2 & 4.1 & 0.8 & 2.9 \\
\hline Significance $^{\mathrm{x}}$ & $\mathbf{L}^{* * *}$ & NS & NS & NS & NS & NS \\
\hline \multicolumn{7}{|c|}{ Paclobutrazol (P) } \\
\hline 50 & 115 & 35.2 & 59.5 & 4.4 & 0.1 & 3.6 \\
\hline 100 & 122 & 29.5 & 55.2 & 4.7 & 0.4 & 3.8 \\
\hline 200 & 116 & 26.3 & 51.2 & 4.4 & 0.5 & 4.0 \\
\hline 400 & 119 & 21.5 & 45.2 & 4.0 & 0.3 & 4.0 \\
\hline Significance & NS & $\mathrm{L}^{* * *} \mathrm{Q}^{*}$ & $\mathrm{~L}^{* *}$ & $Q^{*}$ & NS & $\mathrm{L}^{*} \mathrm{Q}^{*}$ \\
\hline \multicolumn{7}{|c|}{ Uniconazole (U) } \\
\hline 25 & 114 & 26.5 & 51.5 & 4.3 & 0.5 & 3.4 \\
\hline 50 & 118 & 23.7 & 47.8 & 4.8 & 0.5 & 3.6 \\
\hline 100 & 117 & 23.8 & 47.7 & 4.1 & 0.9 & 3.9 \\
\hline 200 & 120 & 17.2 & 39.0 & 4.0 & 0.3 & 2.0 \\
\hline Significance & NS & $\mathrm{L}^{* * *} \mathrm{Q}^{* *}$ & $\mathrm{~L}^{* * *}$ & NS & NS & $Q^{* *}$ \\
\hline P vs. U & NS & $* *$ & $* *$ & NS & NS & NS \\
\hline \multicolumn{7}{|c|}{ Foliar spray } \\
\hline \multicolumn{7}{|l|}{ Daminozide } \\
\hline 2500 & 116 & 47.7 & 69.9 & 4.1 & 0.5 & 3.1 \\
\hline 5000 & 124 & 49.4 & 72.9 & 4.4 & 0.8 & 3.0 \\
\hline Significance & NS & NS & NS & NS & NS & $\mathrm{L}^{*} \mathrm{Q}^{* *}$ \\
\hline \multicolumn{7}{|l|}{ Paclobutrazol } \\
\hline 250 & 115 & 38.6 & 62.4 & 3.7 & 0.3 & 3.0 \\
\hline 500 & 115 & 41.8 & 67.8 & 3.9 & 0.1 & 4.5 \\
\hline Significance & NS & $Q^{*}$ & NS & NS & NS & $\mathrm{L}^{* * *}$ \\
\hline \multicolumn{7}{|l|}{ Uniconazole } \\
\hline 100 & 116 & 40.6 & 63.6 & 3.6 & 0.4 & 4.2 \\
\hline 200 & 117 & 38.6 & 60.1 & 3.2 & 0.5 & 3.8 \\
\hline Significance & NS & $\mathrm{L}^{*}$ & NS & $\mathrm{L}^{*}$ & NS & $\mathrm{L}^{* *} \mathrm{Q}^{* *}$ \\
\hline
\end{tabular}

${ }^{2}$ Internode length between first and second flower.

${ }^{\gamma}$ Begining 13 Oct. 1991.

${ }^{\mathrm{x}} \mathrm{L}=$ linear; $\mathrm{Q}=$ quadratic.

Ns,,$=,+,+x=$ Nonsignificant or significant $\alpha=0.05,0.01$, or 0.001 , respectively. 
Paclobutrazol also restricted internode length between the first two flowers. Its effect was greater when the applications were progressively delayed (Table 3 ). Perhaps the limited mobility of paclobutrazol molecules in plant tissues decreased the ability to restrict elongation when applied early (Barrett and Bartuska, 1982; Wang, 1991). Paclobutrazol did not affect the stalk diameter.

Early stage, Phalaenopsis inflorescence elongation may result primarily through cell division. Therefore, early growth retardant
Table 2. Effect of three growth retardants on second-year performance of Phalaenopsis orchids.

\begin{tabular}{|c|c|c|c|c|c|c|c|c|}
\hline \multirow{2}{*}{$\begin{array}{l}\text { Retardant } \\
\text { rate } \\
\left(\mathrm{mg} \cdot \text { liter }^{-1}\right)\end{array}$} & \multirow{2}{*}{$\begin{array}{c}\text { Inflorescence } \\
\text { emergence } \\
\text { (days) }^{\mathrm{y}}\end{array}$} & \multirow{2}{*}{$\begin{array}{c}\text { First flower } \\
\text { bloom } \\
\text { (days) }^{\mathrm{y}}\end{array}$} & \multirow[b]{2}{*}{$\begin{array}{c}\text { No. } \\
\text { flowers }\end{array}$} & \multicolumn{2}{|c|}{ Stalk $^{2}$} & \multirow{2}{*}{$\begin{array}{c}\text { No. } \\
\text { new } \\
\text { leaves }\end{array}$} & \multicolumn{2}{|c|}{$\begin{array}{l}\text { Uppermost fully } \\
\text { expanded leaf }\end{array}$} \\
\hline & & & & $\begin{array}{l}\text { Length } \\
(\mathrm{cm})^{\mathrm{x}}\end{array}$ & $\begin{array}{c}\text { Diam } \\
(\mathrm{mm})^{\mathrm{w}}\end{array}$ & & $\begin{array}{l}\text { Length } \\
(\mathrm{cm})\end{array}$ & $\begin{array}{l}\text { Width } \\
(\mathrm{cm})\end{array}$ \\
\hline \multicolumn{9}{|l|}{ Control } \\
\hline 0 & 48 & 139 & 10.0 & 57.8 & 6.58 & 4.3 & 23.4 & 10.4 \\
\hline \multicolumn{9}{|c|}{ Preplant dip } \\
\hline \multicolumn{9}{|l|}{ Daminozide } \\
\hline 2500 & 43 & 138 & 12.1 & 62.5 & 6.48 & 4.5 & $21.6^{\circ}$ & 10.6 \\
\hline 5000 & 51 & 150 & 10.1 & 57.9 & 6.41 & 4.6 & 18.8 & 10.0 \\
\hline 7500 & 36 & 133 & 11.0 & 58.5 & 6.45 & 4.4 & 21.1 & 10.1 \\
\hline Significance & NS & NS & NS & NS & NS & NS & NS & NS \\
\hline \multicolumn{9}{|c|}{ Paclobutrazol (P) } \\
\hline 50 & 47 & 139 & 10.8 & 53.4 & 6.40 & 4.8 & 20.5 & 10.8 \\
\hline 100 & 55 & 151 & 10.3 & 54.1 & 6.10 & 6.0 & 19.3 & 10.5 \\
\hline 200 & 75 & 170 & 10.7 & 46.9 & 6.23 & 6.3 & 21.0 & 10.7 \\
\hline 400 & 91 & 177 & 10.4 & 33.2 & 6.01 & 6.0 & 12.8 & 9.9 \\
\hline Significance $\mathrm{v}^{\mathrm{v}}$ & $\mathrm{L}^{* * * *}$ & $\mathrm{~L}^{* *}$ & NS & $\mathbf{L}^{* * *}$ & NS & $\mathrm{L}^{*} \mathrm{Q}^{*}$ & $\mathrm{~L}^{* * *}$ & NS \\
\hline \multicolumn{9}{|l|}{ Uniconazole (U) } \\
\hline 25 & 94 & 183 & 9.0 & 28.0 & 5.24 & 5.8 & 10.6 & 9.5 \\
\hline 50 & 103 & 192 & 9.5 & 31.7 & 5.73 & 7.0 & 11.0 & 10.0 \\
\hline 100 & 109 & 192 & 9.0 & 24.7 & 5.53 & 6.2 & 6.4 & 7.0 \\
\hline 200 & 100 & 194 & 8.8 & 23.9 & 4.98 & 4.8 & 8.4 & 8.2 \\
\hline Significance & $\mathrm{L}^{* *} \mathrm{Q}^{* * *}$ & $\mathrm{~L}^{* *} \mathrm{Q}^{* *}$ & NS & $\mathrm{L}^{* * *} \mathrm{Q}^{* * *}$ & $\mathrm{~L}^{* *}$ & $\mathrm{Q}^{*}$ & $\mathrm{~L}^{* * *} \mathrm{Q}^{* * *}$ & $\mathbf{L}^{*} \mathrm{Q}^{*}$ \\
\hline P vs. U & $* * *$ & $* * *$ & $*$ & $* * *$ & $* *$ & $* *$ & $* * *$ & $* * *$ \\
\hline \multicolumn{9}{|c|}{ Foliar spray } \\
\hline \multicolumn{9}{|l|}{ Daminozide } \\
\hline 2500 & 30 & 116 & 11.9 & 58.1 & 6.36 & 5.1 & 23.8 & 10.5 \\
\hline 5000 & 36 & 133 & 11.6 & 67.6 & 6.95 & 4.4 & 23.7 & 10.1 \\
\hline Significance & NS & $\mathrm{Q}^{*}$ & NS & $\mathrm{L}^{*}$ & NS & NS & NS & NS \\
\hline \multicolumn{9}{|l|}{ Paclobutrazol } \\
\hline 250 & 72 & 163 & 10.3 & 49.4 & 6.05 & 4.7 & 22.0 & 11.1 \\
\hline 500 & 90 & 181 & 10.8 & 48.9 & 6.36 & 7.4 & 17.6 & 11.3 \\
\hline Significance & $\mathrm{L}^{* * *}$ & $\mathrm{~L}^{* * *}$ & NS & $\mathrm{L}^{*}$ & NS & $\mathrm{L}^{* * *}$ & $\mathrm{~L}^{* *}$ & NS \\
\hline \multicolumn{9}{|l|}{ Uniconazole } \\
\hline 100 & 83 & 170 & 10.1 & 43.4 & 6.16 & 6.7 & 15.3 & 11.0 \\
\hline 200 & 80 & 169 & 9.3 & 35.4 & 6.09 & 6.9 & 8.9 & 9.0 \\
\hline Significance & $\mathrm{L}^{*}$ & $\mathrm{~L}^{*}$ & NS & $\mathrm{L}^{* * *}$ & NS & $\mathrm{L}^{* *}$ & $\mathbf{L}^{* * *}$ & NS \\
\hline
\end{tabular}

${ }^{\mathrm{z}}$ Stalk refers to the part of an inflorescence below the first flower.

${ }^{\mathrm{r}}$ Day $0=1$ Sept. 1992 (the date that the first inflorescence started to emerge).

${ }^{x}$ Length from plant attachment to first flower.

wiameter is between the third and fourth internode.

${ }^{\mathrm{v}} \mathrm{L}=$ linear; $\mathrm{Q}=$ quadratic.

${ }^{\mathrm{NS}, *, * * * * *}$ Nonsignificant or significant at $\alpha=0.05,0.01$, or 0.001 , respectively.

Table 3. Effect of paclobutrazol at $250 \mathrm{mg} \cdot$ liter $^{-1}$ on Phalaenopsis orchid flowering when treated at various stages of flower spike development.

\begin{tabular}{|c|c|c|c|c|c|}
\hline \multirow{3}{*}{$\begin{array}{l}\text { Stage or } \\
\text { length of } \\
\text { flower spike }(\mathrm{cm})\end{array}$} & \multicolumn{3}{|c|}{ Inflorescence } & \multicolumn{2}{|c|}{ First flower } \\
\hline & \multicolumn{2}{|c|}{ Length $^{y}$} & \multirow{2}{*}{$\begin{array}{l}\text { Diam } \\
(\mathrm{mm})\end{array}$} & \multirow{2}{*}{$\begin{array}{l}\text { Bloom } \\
\text { (days) }\end{array}$} & \multirow{2}{*}{$\begin{array}{r}\text { Width } \\
(\mathrm{cm})\end{array}$} \\
\hline & $\mathrm{A}(\mathrm{cm})$ & $\mathrm{B}(\mathrm{cm})$ & & & \\
\hline Pre-emergence & $22.1 \mathrm{f}$ & $4.5 \mathrm{~b}$ & $5.9 \mathrm{ab}$ & $94.0 \mathrm{a}$ & $10.2 \mathrm{c}$ \\
\hline Emergence & $27.8 \mathrm{e}$ & $4.3 b$ & $5.6 \mathrm{ab}$ & $87.7 \mathrm{~b}$ & $10.2 \mathrm{c}$ \\
\hline 1.0 & $31.5 \mathrm{~d}$ & $4.2 \mathrm{bc}$ & $5.6 \mathrm{~b}$ & $78.5 \mathrm{e}$ & $10.3 \mathrm{c}$ \\
\hline 2.5 & $35.5 \mathrm{c}$ & $3.9 \mathrm{~cd}$ & $5.5 \mathrm{~b}$ & $87.8 \mathrm{~b}$ & $10.2 \mathrm{c}$ \\
\hline 5.0 & $37.8 \mathrm{bc}$ & $3.9 \mathrm{~cd}$ & $6.0 \mathrm{a}$ & $81.4 \mathrm{de}$ & $10.6 \mathrm{ab}$ \\
\hline 7.5 & $39.0 \mathrm{~b}$ & $3.7 \mathrm{de}$ & $5.7 \mathrm{ab}$ & $87.1 \mathrm{bc}$ & $10.4 \mathrm{bc}$ \\
\hline 10.0 & $40.5 b$ & $3.5 \mathrm{e}$ & $5.8 \mathrm{ab}$ & $84.3 \mathrm{~cd}$ & $10.6 \mathrm{a}$ \\
\hline Control & $48.7 \mathrm{a}$ & $4.9 \mathrm{a}$ & $5.8 \mathrm{ab}$ & $93.5 \mathrm{a}$ & $10.2 c$ \\
\hline
\end{tabular}

${ }^{2}$ Mean separation within columns by Duncan's multiple range at $\alpha=0.05$. Differences in flower count (7.98.9) were nonsignificant.

${ }^{\mathrm{y}} \mathrm{A}=$ distance between the base and the node bearing the first flower; $\mathrm{B}=$ internode length between the first two flowers.

${ }^{x}$ Day $0=5$ Nov. 1992 . application exerts a greater effect by limiting the number of cells. Daminozide limited the cell count of chrysanthemum [Dendranthema $\times$ grandiflorum (Ramat.) Kitamura] internode to one-third that of a nontreated plant (Jin et al., 1992). Uniconazole also curtails cell count and size, resulting in short hibiscus pedicels (Wang and Dunlap, 1994).

Concentration effect. Neither the number of paclobutrazol applications at 125 to 500 $\mathrm{mg} \cdot$ liter $^{-1}$ nor the paclobutrazol concentration had an effect on flower size or number (Table 4). Stalk length was restricted in all treated plants, with little dosage effect. The internode length between the first two flowers was shorter as the result of one paclobutrazol application at all concentrations. Surprisingly, two applications had no effect. Also, paclobutrazol concentrations had no effect on stalk diameter (Table 4).

Because plants produced inflorescences uniformly, plants of various stages had to be selected and treated on several dates. This procedure invalidated evaluation of paclobutrazol on bloom date in the second experiment However, plants treated at the pre-emergence stage, resulting in the shortest stalk, bloomed at the same time as the nontreated plants (Table 3 ). Therefore, as observed in the first experiment, paclobutrazol treatments probably did not accelerate or delay flowering in the current season.

This study demonstrates that paclobutrazol and uniconazole successfully control Phalaenopsis inflorescence length without affecting visual flower quality. However, when used at high concentrations, these substances will delay or prevent the following year's bloom, as well as cause the production of more small, thick leaves. Daminozide is not suitable for controlling the inflorescence length of Phalaenopsis.

\section{Literature Cited}

Barrett, J.E. and C.A. Bartuska. 1982. PP-333 effects on stem elongation dependent on site of application. HortScience 17:737-738.

Gavin, A. and R.J. Griesbach. 1991. Phalaenopsis parishii: Color variations and hybrids. Amer. Orchid Soc. Bul. 60:121-124.

Gordon, B. 1990. Culture of the Phalaenopsis orchid, Laid-Back Publications, Rialto, Calif.

Griesbach, R.J. 1985. Phalaenopsis orchids as potential pot plants. HortScience 20:624.

Jin, B., H. Dong, D. Mu, X. Yang, Y. Wang, and X. Xu. 1992. Studies on the mechanism of action of B-Nine in reducing stem elongation of chrysanthemum. Acta Hort. Sinica 19(2):171174 ,

McDowell. D. 1992. At home with Phalaenopsis. Amer. Orchid. Soc. Bul. 61:150-153.

Poole, H.A. and J.G. Seeley. 1977. Effects of artificial light sources, intensity, watering frequency and fertilization practices on growth of Cattleya, Cymbidium and Phalaenopsis orchids. Bul. Amer. Orchid Soc. 46(10):923-928.

Taiwan Sugar. 1989. Manual for cultivating Phalaenopsis orchids, Taiwan Sugar, Corp., Taipei.

Thomas, S.H. 1992. Demand over paces production of the optimum orchid. Greenhouse Grower 11(5):56-59. 
Table 4. Effect of paclobutrazol at various concentrations on the flowering response of Phalaenopsis orchids. ${ }^{\text {. }}$

\begin{tabular}{|c|c|c|c|c|c|c|}
\hline \multirow{3}{*}{$\begin{array}{l}\text { Rate } \\
\left(\mathrm{mg} \cdot \text { liter }^{-1}\right)\end{array}$} & \multicolumn{2}{|c|}{ First flower } & \multirow{3}{*}{$\begin{array}{c}\text { No. } \\
\text { flower }\end{array}$} & \multicolumn{3}{|c|}{ Inflorescence } \\
\hline & \multirow{2}{*}{$\begin{array}{l}\text { Bloom } \\
\text { (days) }\end{array}$} & \multirow{2}{*}{$\begin{array}{l}\text { Width } \\
(\mathrm{cm})\end{array}$} & & \multicolumn{2}{|c|}{ Length $^{x}$} & \multirow{2}{*}{$\begin{array}{c}\text { Diam }^{\mathrm{w}} \\
(\mathrm{mm})\end{array}$} \\
\hline & & & & $\mathrm{A}(\mathrm{cm})$ & $\mathrm{B}(\mathrm{cm})$ & \\
\hline 0 & $93.5 \mathrm{a}$ & $10.2 \mathrm{a}$ & $8.1 \mathrm{a}$ & $48.7 \mathrm{a}$ & $4.9 \mathrm{a}$ & $5.8 \mathrm{ab}$ \\
\hline 125 & $83.8 \mathrm{~b}$ & $10.1 \mathrm{a}$ & $8.3 \mathrm{a}$ & $35.9 \mathrm{~b}$ & $4.4 b$ & $5.8 \mathrm{ab}$ \\
\hline $125 \times 2$ & $81.1 \mathrm{bc}$ & $10.1 \mathrm{a}$ & $8.1 \mathrm{a}$ & $35.5 \mathrm{~b}$ & $4.8 \mathrm{a}$ & $5.5 \mathrm{~b}$ \\
\hline 250 & $78.5 \mathrm{c}$ & $10.3 \mathrm{a}$ & $7.9 \mathrm{a}$ & $31.5 \mathrm{c}$ & $4.2 \mathrm{~b}$ & $5.6 \mathrm{~b}$ \\
\hline $250 \times 2$ & $79.6 \mathrm{bc}$ & $10.2 \mathrm{a}$ & $8.7 \mathrm{a}$ & $36.2 \mathrm{~b}$ & $4.8 \mathrm{a}$ & $6.0 \mathrm{a}$ \\
\hline 500 & $80.0 b c$ & $10.3 \mathrm{a}$ & $8.2 \mathrm{a}$ & $33.5 b c$ & $4.1 \mathrm{~b}$ & $5.8 \mathrm{ab}$ \\
\hline
\end{tabular}

"Mean separation within columns by Duncan's multiple range test at $\alpha=0.05$.

${ }^{y}$ For 0 and $250 \mathrm{mg} \cdot \mathrm{miter}^{-1}$, day $0=5$ Nov. 1992; for all others, day $0=18 \mathrm{Nov} .1992$.

${ }^{\times} \mathrm{A}=$ distance between the base and the node bearing the first flower; $\mathrm{B}=$ internode length between the first two flowers.

"Measured at the middle of the fourth internode.
Vasquez, G. and M.C. Frier. 1991. International taste in Phalaenopsis hybrids. Amer. Orchid Soc. Bul. 60(1):10-14.

Wang, Y.T. 1991. Growth stage and site of application affect efficacy of uniconazole and $\mathrm{GA}_{3}$ in hibiscus. HortScience 26:148-150.

Wang, Y.T. 1992. Phalaenopsis: The easy-to-grow orchid. Greenhouse Grower 11(3):90, 92.

Wang, Y.T. and J.R. Dunlap. 1994. Effect of $\mathrm{GA}_{4+7}$ on growth and cellular change in uniconazoletreated hibiscus. J. Plant Growth Regulat. (In press.)

Wang, Y.T. and L.L. Gregg. 1991. Modification of hibiscus growth by treating unrooted cuttings and potted plants with uniconazole or paclobutrazol. J. Plant Growth Regulat. 10:4751. 